\title{
Treatments of Magnesium slag to Recycle Waste from Pidgeon Process
}

\author{
Fenglan Han ${ }^{1,}$ a, Qixing Yang ${ }^{2, b}$, Laner $\mathrm{Wu}^{1, \mathrm{c}}$ and Shengwei Guo ${ }^{1, \mathrm{~d}}$ \\ ${ }^{1}$ School of Material Science \& Engineering, Beifang University of Nationalities, Yinchuan, Ningxia \\ 750021, China \\ ${ }^{2}$ Minerals and Metals Research Laboratory, Luleå University of Technology, SE-971 87, Luleå, \\ Sweden \\ ª625477897@qq.com, 'bixing.yang@ltu.se, 'lanerwu@126.com, ${ }^{\text {d }}$ feidehai@163.com
}

Keywords: Magnesium, Pidgeon Process, Slag, Disintegration, Valorization, Sintering, Stabilization, Building Material, Borates

\begin{abstract}
Magnesium slag powder from a local magnesium plant was treated to improve the volume stability for its application as building materials. The slag was mixed with borates, pressed into briquettes, and then sintered at high temperature. SEM studies show that at the higher temperature $\mathrm{Ca}_{2} \mathrm{SiO}_{4}$ polymorphs were stabilized by $\mathrm{Na}$ and $\mathrm{B}$ ions in the added borates. The free $\mathrm{MgO}$ content in the slag was also decreased by the sintering treatment. The slag powder, after mixing with $0.4-0.6 \%$ of borates and sintered at $1200^{\circ} \mathrm{C}$ in 5-6 hours, has become volume stable aggregates. It is then possible to use the treated slag in constructions, saving valuable natural resources and decreasing the global warming impact from magnesium production via Pidgeon process.
\end{abstract}

\section{Introduction}

Primary Magnesium Production In China. Many of new applications of magnesium metal and alloys in automotive, electronic and steel industries [1-5] have led to a steady growth in the world demand for magnesium in the last 15 years. China, thus, has emerged as the largest producer of primary magnesium in the world to meet the increasing demand for magnesium. A high speed increase in the Chinese production of magnesium started from 1990s [6] and, by the end of year 2005, the capacity and output of primary magnesium have reached 816000 and 467600 tons, respectively. The volume of magnesium export from China in 2005 amounted to 353100 tons, which was approximately $70 \%$ of the global magnesium production [7].

The rapid Chinese advancement in the primary magnesium output is due, firstly, to very rich magnesium sources and raw materials available in China, including lake brines, dolomite and magnesite [8]. Another factor is that all of the magnesium producers adopt Pidgeon process with some local modifications [9-11], by which some advantages of the Pidgeon process, fewer production steps, lower equipment investments and higher product quality, can be combined together in an optimum way with low costs for raw materials, energy and labors in many Chinese regions, leading to a very competitive production of primary magnesium.

Pidgeon Process. The Pidgeon process, invented in 1940s in Canada by Pidgeon LM [12], is a thermal process using dolomite as the raw material. Eq. 1 describes the overall reaction for the process [11, 13-14]:

$$
2 \mathrm{CaO} \cdot \mathrm{MgO}(\mathrm{s})+(\mathrm{Fe}) \mathrm{Si}(\mathrm{s}) \rightarrow 2 \mathrm{Mg}(\mathrm{g})+\mathrm{Ca}_{2} \mathrm{SiO}_{4}(\mathrm{~s})+\mathrm{Fe}(\mathrm{s})
$$

The first step to run the reaction in modern magnesium plants is to charge briquettes made of calcined dolomite, e.g. $\mathrm{CaO} \cdot \mathrm{MgO}$, and ferrosilicon into retorts inside reduction furnaces. The retorts are heated, after the charging, to a temperature around $1200^{\circ} \mathrm{C}$ with a vacuum of $1.3-10 \mathrm{~Pa}$ maintained inside, by which magnesium vapor is generated from Si-reduction of $\mathrm{MgO}$. The vapor condenses at the water-cooled feed end of the retort, forming a crystalline magnesium crown. The magnesium crowns are then refined to produce magnesium ingots [10-14]. The briquettes after the $\mathrm{MgO}$ reduction are discharged from the retorts as a by-product or waste. 
The Chinese magnesium production via Pidgeon process is not only cost-effective. On the other hand it is also energy and natural-resource intensive. There are several studies of environmental issues relating to the magnesium production, including emissions of air pollutants [11] and global warming impact $[11,14]$. The global warming impact of magnesium production in China has been estimated near to $42 \mathrm{~kg} \mathrm{CO}$ eq/ $/ \mathrm{kg} \mathrm{Mg}$ ingot [14], which is related largely to a high materials input.

Waste From Pidgeon Process -The Magnesium Slag. Some calculations have shown that pellets or briquettes of $6.678 \mathrm{~kg}$, made of calcined dolomite $(5.385 \mathrm{~kg})$, ferrosilicon $(1.19 \mathrm{~kg})$ and calcium fluoride, are needed for producing $1.096 \mathrm{~kg}$ crown magnesium [14], thus, generating a solid by-product or waste, the Magnesium slag, weighing $5.582 \mathrm{~kg}(6.678-1.096)$. (The Magnesium slag is hereafter abbreviated as Mg slag.) This implies a generation of about $6 \mathrm{~kg}$ waste slag from production of $1 \mathrm{~kg} \mathrm{Mg}$ ingot. Some similar figures are also reported in other literatures, 6.5-8 tons of waste $\mathrm{Mg}$ slag discharged for per ton of magnesium produced [15-16]. The waste Mg slag of large volumes should be recycled or used as raw materials in construction, similar to the BOF and EAF slag from steel production [17], thereby decreasing the global warming impact.

Eq. 1 reveals some special characters of the $\mathrm{Mg}$ slag. On right hand side of the equation, there are two solid products, dicalcium silicate, e.g. $\mathrm{Ca}_{2} \mathrm{SiO}_{4}(\mathrm{~s})$, and $\mathrm{Fe}(\mathrm{s})$, remaining in the reaction system, the briquettes, which have become a process waste after the reaction. The metallic $\mathrm{Fe}(\mathrm{s})$ may be oxidized completely by atmosphere air during cooling from the discharging temperature, estimated near $1000^{\circ} \mathrm{C}$. The $\mathrm{Ca}_{2} \mathrm{SiO}_{4}$, a major product inside the briquettes, undergoes several phase transformations during the cooling. One is the transformation from $\beta$ to $\gamma$ phase of the $\mathrm{Ca}_{2} \mathrm{SiO}_{4}$ that takes place in temperature range of $400-500^{\circ} \mathrm{C}$ and incurs a volume expansion of approximately $12 \%$ [18-22]. By the volume expansion the solid briquettes disintegrate, generating fines of $\mathrm{Mg}$ slag [10, $15,21,22]$.

Besides the $\gamma-\mathrm{Ca}_{2} \mathrm{SiO}_{4}$, there are also some percents of free $\mathrm{CaO}$ and $\mathrm{MgO}[21,22]$, which will hydrate, while in contact with water, causing long term volumetric instability for the slag [23-25].

The special and negative characters have made it rather difficult to use the Mg slag powder as building materials or aggregates for road construction. A large part of the generated $\mathrm{Mg}$ slag has to be deposited near magnesium plants, wasting valuable natural resources, occupying farming lands of large area and with slag dusts dispersing in atmosphere to cause pollutions of water and air surrounding the plants [15, 16, 23-25].

Some Early Work On Valorization of Mg Slag And steel Slags. There have been numbers of Chinese studies regarding utilizations of the Mg slag. It has been shown by TGA tests that Mg slag particles of $0.105 \mathrm{~mm}$ can be used for desulphurization of hot waste gas from industrial boilers [15]. Congyun Huang et al. found a positive effect on clinkerization and a rather large increase in compressive strengths for the burned Portland cement clinker when $20 \%$ limestone was replaced by $\mathrm{Mg}$ slag in the clinker raw materials [16].

Zizhi Cui et al. studied expansion mechanisms for Mg slag [23] and increased activity of the slag in cement mortars by fast slag cooling and by mixing the slag with fly ash [24]. The Mg slag has also been ground to particles of $0.08 \mathrm{~mm}$ and mixed with other waste materials and activation agent to use as binders for making high strength building bricks [25].

Qixing Yang et al. carried out laboratory tests to treat several dusting, e.g. disintegrating, steel slags, including AOD [18, 19], EAF [26] and reduction slag [27]. Agents containing $\mathrm{B}_{2} \mathrm{O}_{3}$ and $\mathrm{P}_{2} \mathrm{O}_{5}$ were melted together with the slag fines. The slag fines were also re-melted and then granulated by water or gas $[18,26,27]$ for a fast cooling. The samples after the treatments were volumetric stable and able to use as slag products in construction.

Dirk Durinck studied borate distributions in slowly cooled synthetic and industrial slag samples and found only small part of the added borates forming a solid solution with $\mathrm{Ca}_{2} \mathrm{SiO}_{4}$ phase $[21,28]$. Their results indicated that adding more borates in liquid slag is the only way to raise the borate level in the $\mathrm{Ca}_{2} \mathrm{SiO}_{4}$ phase, rather than changing the slag composition [28]. 
On The Present Work. The present work was undertaken for enhancing utilization of Mg slag in construction. Results from the early work of slag valorization [15-28] were referred to, including the work of treating the steel slags with a disintegration behavior. A slag sample was obtained from a magnesium factory for laboratory treatment tests. Small square briquettes were prepared from the slag mixed with borate agents for sintering tests in an electrical furnace. Samples of the $\mathrm{Mg}$ slag and sintered briquettes were characterized.

Results from the present work, reported and discussed in this paper, may lead to some suggestions for new methods for treatment of the Mg slag fines. It may then be possible, with the treatment, to increase the degree of utilization of the $\mathrm{Mg}$ slag as building materials, hence, saving valuable natural resources and reducing the global warming impact caused by the magnesium production.

\section{METHODOLOGY}

The materials - Borate Agents. Chemical stabilization by using borate based stabilizers, i.e. borate agents, is a simple way for steel industry to prevent a $\gamma-\mathrm{Ca}_{2} \mathrm{SiO}_{4}$-driven slag disintegration [18-22]. The agents with a quantity of around $1-2 \%$ of slag weight are usually added in liquid slag during the slag tapping. Mixtures of borates and slag fines have also been re-melted in laboratory furnaces to obtain results for improving industry operations of the slag treatment [19, 21].

Three borate agents were selected to treat the $\mathrm{Mg}$ slag powder from the magnesium factory. Some of the agent data are listed in Table 1. Dehybor, i.e. $\mathrm{Na}_{2} \mathrm{~B}_{4} \mathrm{O}_{7}$, and G-Vitribore 25 are commercially available borate products, hereafter abbreviated as $\mathrm{DB}$ and $\mathrm{GB}$, respectively. Besides $\mathrm{B}_{2} \mathrm{O}_{3}, \mathrm{Na}_{2} \mathrm{O}$ in both DB and GB is also effective for crystal chemical stabilization of higher temperature $\mathrm{Ca}_{2} \mathrm{SiO}_{4}$ polymorphs [20]. The melting point of GB is $696^{\circ} \mathrm{C}$ [22], lower by $46^{\circ} \mathrm{C}$ than the one for $\mathrm{DB}$. The two borate agents have been adopted by many plants to treat dusting steelmaking slags [19, 22].

$96 \%$ of particles in GB pass through $1.16 \mathrm{~mm}$ sieve. DB is finer than GB. The $\mathrm{H}_{3} \mathrm{BO}_{3}$, a chemical, was ground to fine particles before using.

Table 1: Oxide contents in [mass fraction \%] and melting point in $\left[{ }^{\circ} \mathrm{C}\right]$ for borate agents

\begin{tabular}{|c|c|c|c|c|c|c|c|}
\hline & $\mathrm{CaO}$ & $\mathrm{SiO}_{2}$ & $\mathrm{~B}_{2} \mathrm{O}_{3}$ & $\mathrm{Na}_{2} \mathrm{O}$ & $\mathrm{MgO}$ & $\mathrm{P}_{2} \mathrm{O}_{5}$ & Melting point \\
\hline DB (Dehybor) & & & 69 & 30.8 & & & 742 \\
\hline GB (G-Vitribore 25) & 8.8 & 29.4 & 23.5 & 23.5 & 0.3 & 1.4 & 696 \\
\hline $\mathrm{H}_{3} \mathrm{BO}_{3}$ & & & 56.5 & & & & \\
\hline
\end{tabular}

Sintering of Briquettes Made Of Slag-Borate Mixture. A dry powder of Mg slag weighing 30 grams was first mixed with one type of the 3 borate agents. The agents added were in the range of $0-1 \%$ of the slag weight. The slag-agent mixtures were then pressed for 20 seconds by a force of 5 tons to form square briquettes with length and width both equal to 40 or $50 \mathrm{~mm}$ and with heights ranging 6-11 mm.

The newly formed briquettes were placed on surface of a refractory brick in an electric furnace for sintering, which started by raising the furnace temperature to $1200^{\circ} \mathrm{C}$ in approximately 6 hours. After maintaining the temperature of $1200^{\circ} \mathrm{C}$ for periods of 2-6 hours, the furnace was power off with the sintered briquettes inside to cool naturally. The cooling from $1200^{\circ} \mathrm{C}$ to room temperature took about 10-12 hours. The cold briquettes were then examined to evaluate treatment effects, including visual observations and measurements of briquette dimensions.

Characterizations And FactSage Simulation of slag phases. X-ray diffraction analysis, XRD, was performed on pulverized Mg slag and briquette samples with a SHIMADZU XRD-6000 diffractometer. A SHIMADZU SSX-550 Scanning Electron Microscope equipped with energy dispersive spectroscopy, SEM-EDS, was used to study morphology and element distribution of the polished samples of sintered briquettes. Major mineral phases formed under equilibrium condition in the temperature range for the slag cooling are predicted by FactSage 6.2 thermodynamic package [29]. 


\section{RESULTS AND DISCUSSION}

Characters Of Mg Slag Sample And Slag Phases Predicted By FactSage. The original Mg slag is rather fine, with a $\mathrm{d}_{95}$ of $99.5 \mu \mathrm{m}$, as seen in Fig. $1 . \mathrm{MgO}$ content in the slag is $5.12 \%$ and content ratio of $\mathrm{CaO}$ to $\mathrm{SiO}_{2}$, i.e. the basicity, for the slag is 1.58 , referring to Table 2. The basicity for the $\mathrm{Mg}$ slag is rather similar to basicity values for some AOD slag disintegrated to powder during cooling, due to formation of $\gamma-\mathrm{Ca}_{2} \mathrm{SiO}_{4}[18,19,21,27]$.

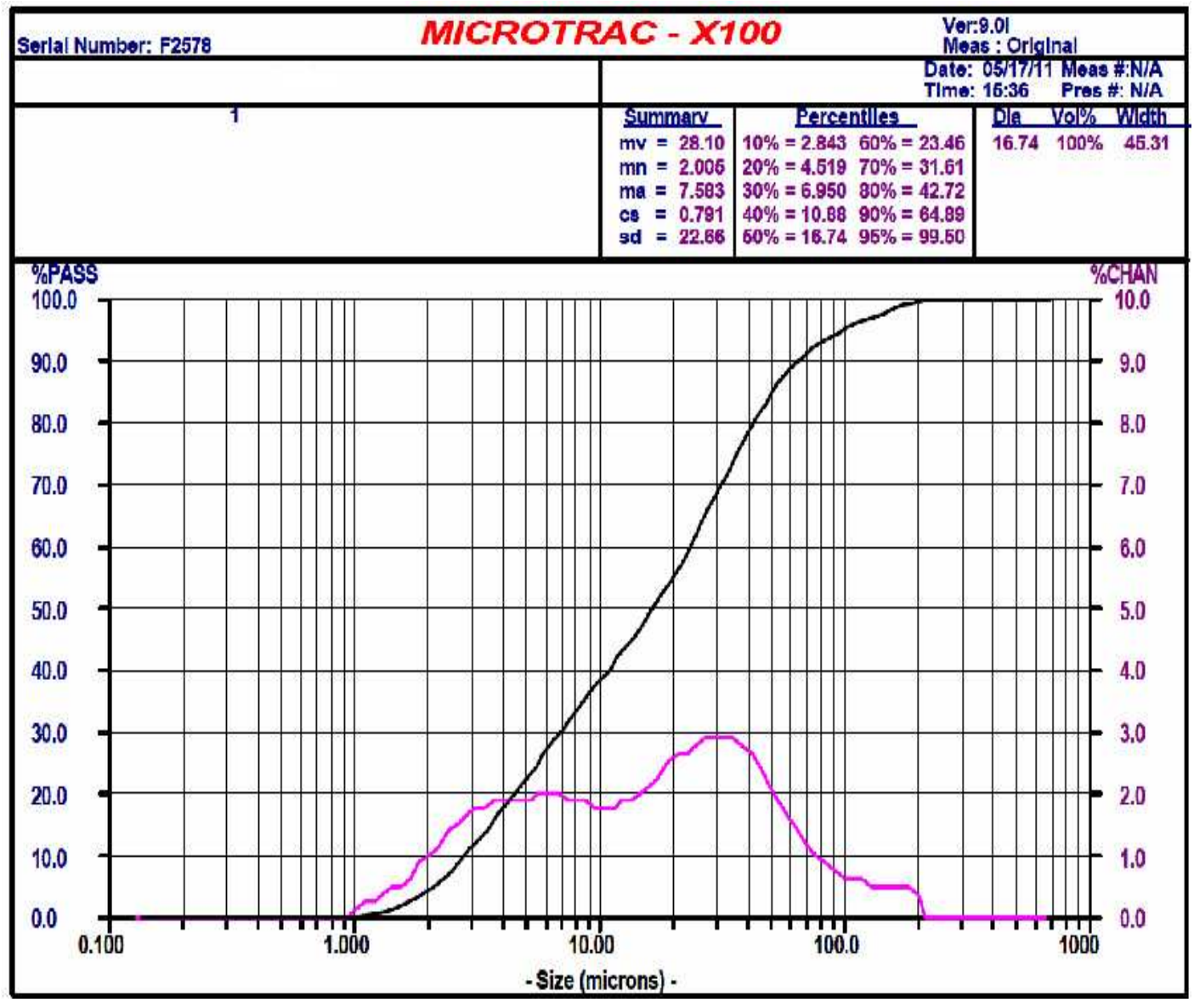

Fig. 1: Particle size distribution of the Mg slag used in the present work

Table 2: Oxide and element analyzed in the Mg slag, [weight \%]

\begin{tabular}{|c|c|c|c|c|c|c|c|c|}
\hline $\mathrm{MgO}$ & $\mathrm{CaO}$ & $\mathrm{SiO}_{2}$ & $\mathrm{P}_{2} \mathrm{O}_{5}$ & $\mathrm{Fe}$ & $\mathrm{Al}$ & $\mathrm{Mn}$ & $\mathrm{Na}$ & $\mathrm{CaO} / \mathrm{SiO}_{2}$ \\
\hline 5.12 & 42.35 & 26.78 & 0.061 & 3.85 & 0.604 & 0.061 & 0.979 & 1.58 \\
\hline
\end{tabular}

Table 3: Adjusted composition of Mg slag for FactSage 6.2 calculation, [weight \%]

\begin{tabular}{|c|c|c|c|c|c|}
\hline $\mathrm{MgO}$ & $\mathrm{CaO}$ & $\mathrm{SiO}_{2}$ & $\mathrm{Fe}_{2} \mathrm{O}_{3}$ & $\mathrm{Al}_{2} \mathrm{O}_{3}$ & $\mathrm{Na}_{2} \mathrm{O}$ \\
\hline 5.8 & 48.3 & 30.5 & 12.5 & 1.3 & 1.5 \\
\hline
\end{tabular}

Results of XRD analysis are presented in Fig. 2. For sample (a) of the original $\mathrm{Mg}$ slag, $\gamma-\mathrm{Ca}_{2} \mathrm{SiO}_{4}$, abbreviated as $\gamma-\mathrm{C}_{2} \mathrm{~S}$, exists as a major phase causing the slag disintegration. There are $\mathrm{CaF}_{2}$ and free $\mathrm{MgO}$ present in the sample as minor phases. $\beta-\mathrm{C}_{2} \mathrm{~S}\left(\beta-\mathrm{Ca}_{2} \mathrm{SiO}_{4}\right)$ is also detected as a minor phase, indicating that some small amount of $\beta-\mathrm{C}_{2} \mathrm{~S}$ may survive from a fast cooling for some slag particles.

Compared with sample (a) in Fig. 1, less $\gamma-\mathrm{C}_{2} \mathrm{~S}$ phase was detected in the sample (b), demonstrating that the transformation of $\gamma-\mathrm{C}_{2} \mathrm{~S}$ to $\beta-\mathrm{C}_{2} \mathrm{~S}$ was restrained by adding borate agent, $0.53 \%$ DB. Both $\mathrm{CaF}_{2}$ and free $\mathrm{MgO}$ could hardly be found in the sintered sample (b). A part of the $\mathrm{MgO}$ might form solid solutions with other volume stable minerals during the sintering. 


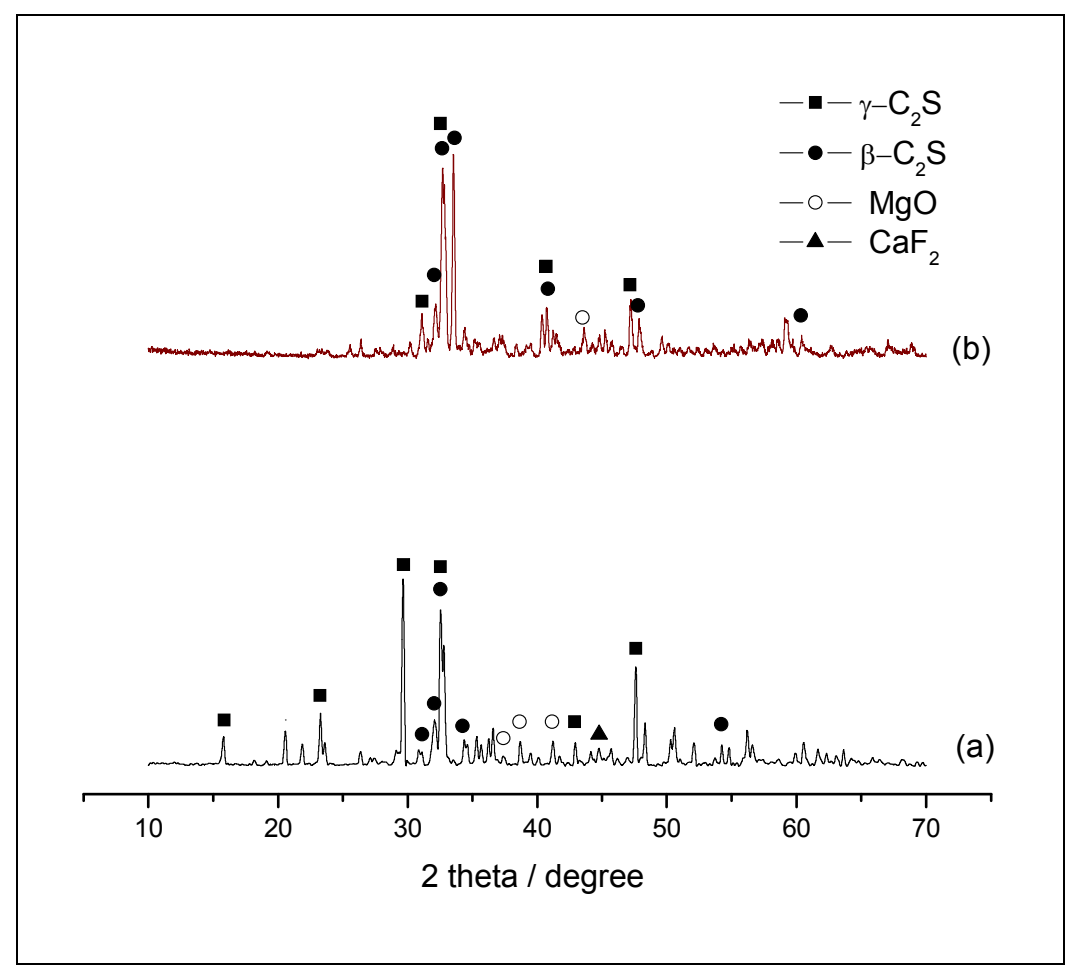

Fig. 2: XRD pattern of original Mg slag (a) and sintered slag-borate mixture with $0.53 \% \mathrm{DB}$ (b)

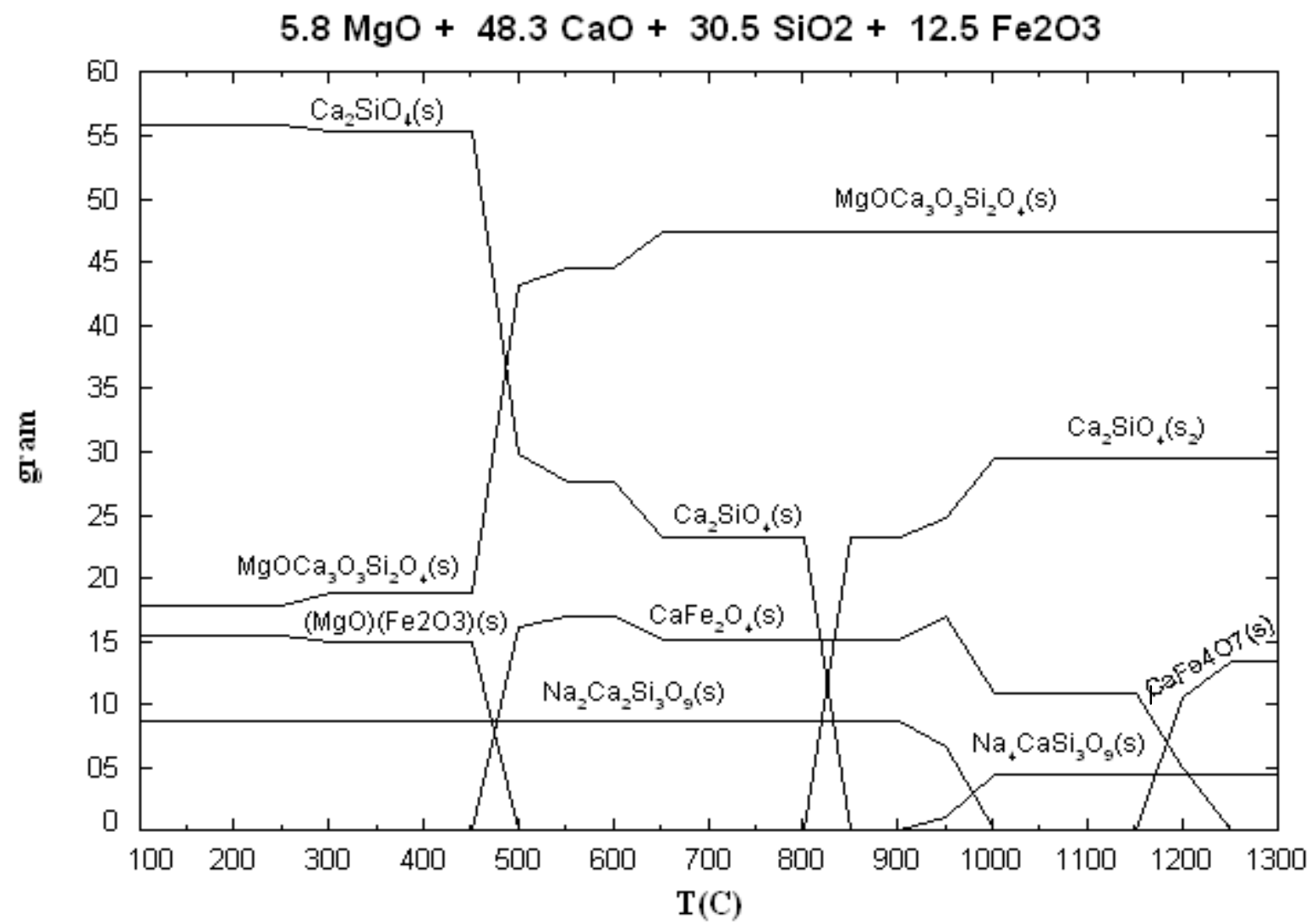

Fig. 3: Equilibrium phase distribution, in gram or weight percent, during cooling of the $\mathrm{Mg}$ slag in temperature range of $1300-100^{\circ} \mathrm{C}$ calculated by FactSage 6.2 
The composition of $\mathrm{Mg}$ slag in Table 2 was adjusted in Table 3 as input data for the thermodynamic calculation using FactSage 6.2. The amounts of major mineral phases, in gram or weight percent, formed in the slag were calculated in a temperature range of $1300-100^{\circ} \mathrm{C}$ and at a pressure of 1 atmosphere. The program simulates only formations of $\gamma$ and $\alpha^{\prime}$ polymorphs of $\mathrm{Ca}_{2} \mathrm{SiO}_{4}$.

The $\mathrm{Ca}_{2} \mathrm{SiO}_{4}\left(\mathrm{~s}_{2}\right)$, e.g. $\alpha^{\prime}-\mathrm{Ca}_{2} \mathrm{SiO}_{4}$ polymorphs, may only be $29 \%$ at higher temperature, $1300-1000^{\circ} \mathrm{C}$ as seen in Fig. 3. The $\mathrm{MgOCa}_{3} \mathrm{O}_{3} \mathrm{SiO}_{4}(\mathrm{~s})$, e.g. merwinite formed by $\mathrm{MgO}, \mathrm{CaO}$ and $\mathrm{SiO}_{2}$, is a major phase with content of $47 \%$ from 1300 to $650^{\circ} \mathrm{C}$. But the merwinite decomposes largely at around $500^{\circ} \mathrm{C}$ and becomes a minor one with the phase content of $17.5 \%$ near to room temperature. As a result the $\mathrm{Ca}_{2} \mathrm{SiO}_{4}(\mathrm{~s})$, e.g. $\gamma-\mathrm{Ca}_{2} \mathrm{SiO}_{4}$ polymorphs, turns into a major phase of $56 \%$ near to room temperature. Any slag with a similar $\gamma-\mathrm{Ca}_{2} \mathrm{SiO}_{4}$ content will disintegrates to fine powder or dusts.

Effects Of Sintering On Characters Of Briquette Samples. A part of the sintered briquettes are shown by pictures in Figs. 4 and 5. Without borates addition, the sintered briquettes are fractured to small pieces and particles by volume expansion and retain their color of origin, a light grey color for the Mg slag, like the briquettes with No. 55 in both Figs. 4 and 5. By mixing with borates of $0.34-0.95 \%$, the sintered briquettes become more compact and smaller, with their color changing to dark brown, as observed for briquettes No. 1 and 25 in Fig. 4 and No. 37, 25 and 15 in Fig. 5.

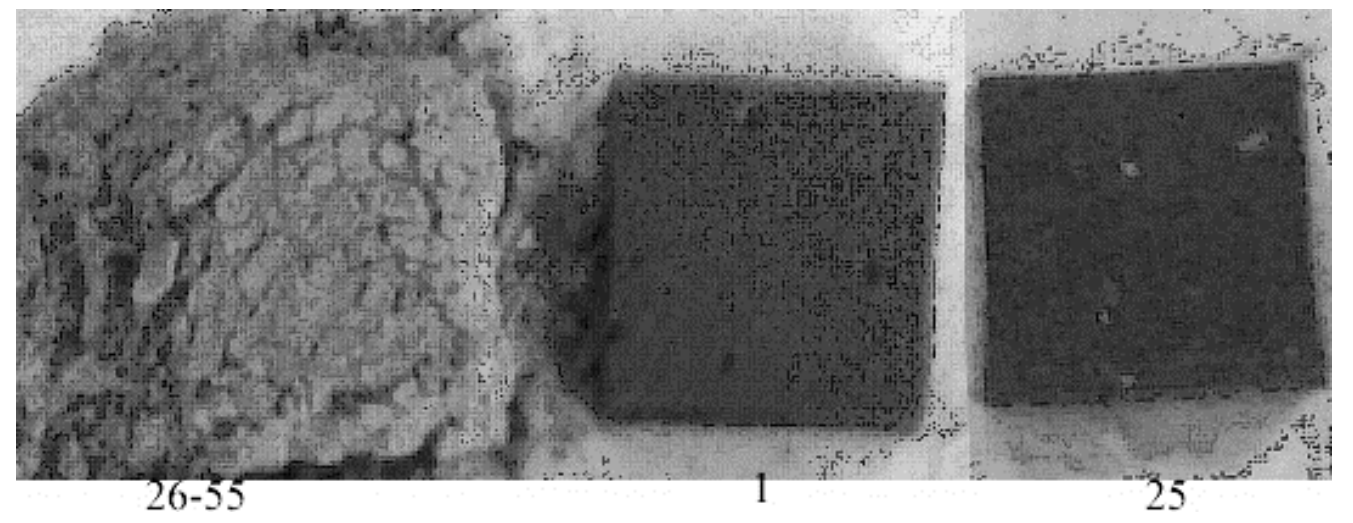

Fig. 4: Picture of briquettes from test 26 sintered at $1200^{\circ} \mathrm{C}$ for 5 hours, borate agents added in weight percent of Mg slag for the briquettes from left to right with number (No.): No borate agent added in No. $55,0.53 \%$ DB in No. 1 , and $0.54 \%$ GB in No. 25

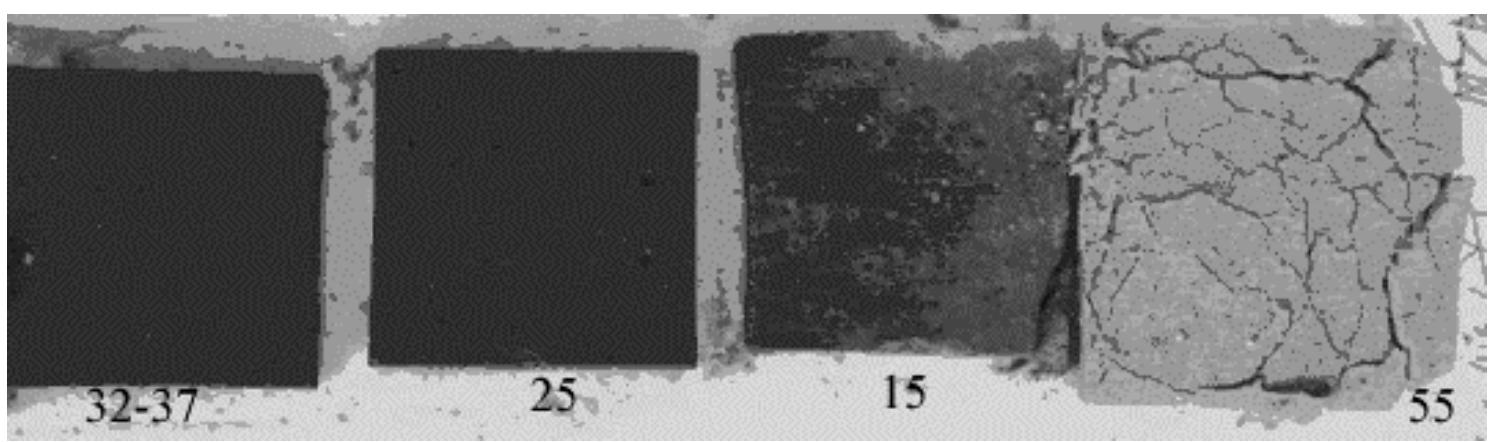

Fig. 5: Picture of briquettes from test 32 sintered at $1200^{\circ} \mathrm{C}$ for 6 hours, borate agents added in weigh percent of $\mathrm{Mg}$ slag for the briquettes from left to right with number (No.): $0.59 \% \mathrm{H}_{3} \mathrm{BO}_{3}$ in No. $37,0.95 \% \mathrm{H}_{3} \mathrm{BO}_{3}$ in No. 25, 0. 34\% DB in No. 15 and No borate agent added in No. 55

A lower percents of borates added can result in smaller changes in the briquette color and dimensions, as well as damages or cracks in some briquette parts. This can be demonstrated by comparing the briquettes in Fig. 5. Briquette No. 15, added less borate, DB of $0.34 \%$, by comparison 
with briquette No. 37 and 25 , adding $\mathrm{H}_{3} \mathrm{BO}_{3}$ of $0.59 \%$ and $0.95 \%$, respectively. Thus the color is less dark and there are some damages near the right hand side for briquette No. 15, indicating a lower degree of volume stabilization for the Mg slag.

All briquettes, including briquettes with high percents of borate addition disintegrated while sintered for a time less than 2.5 hours. When sintering the briquettes in 3-5 hours, inconsistent results were often obtained. Dimensions were measured before and after the briquette sintering to compute volume reduction of briquettes sintered for different periods by using the measured briquette length, width and height in Eq. 2. It is seen in Fig. 6 that, with additions of DB and GB of $0.4-0.54 \%$ and sintering for 6 hours, the briquette volume reductions reach to 24-31\%. With similar amounts of the borate addition, but decreasing the sintering time to 3 hours, the volume reductions decrease to lower values, $14-20 \%$.

$$
\begin{aligned}
& \text { Volume reduction for briquette, } \%,= \\
& \frac{(\text { Length } \times \text { Width } \times \text { Height })_{\text {before sintering }}-(\text { Length } \times \text { Width } \times \text { Height })_{\text {after sintering }}}{(\text { Length } \times \text { Width } \times \text { Height })_{\text {before sintering }}} \times 100
\end{aligned}
$$

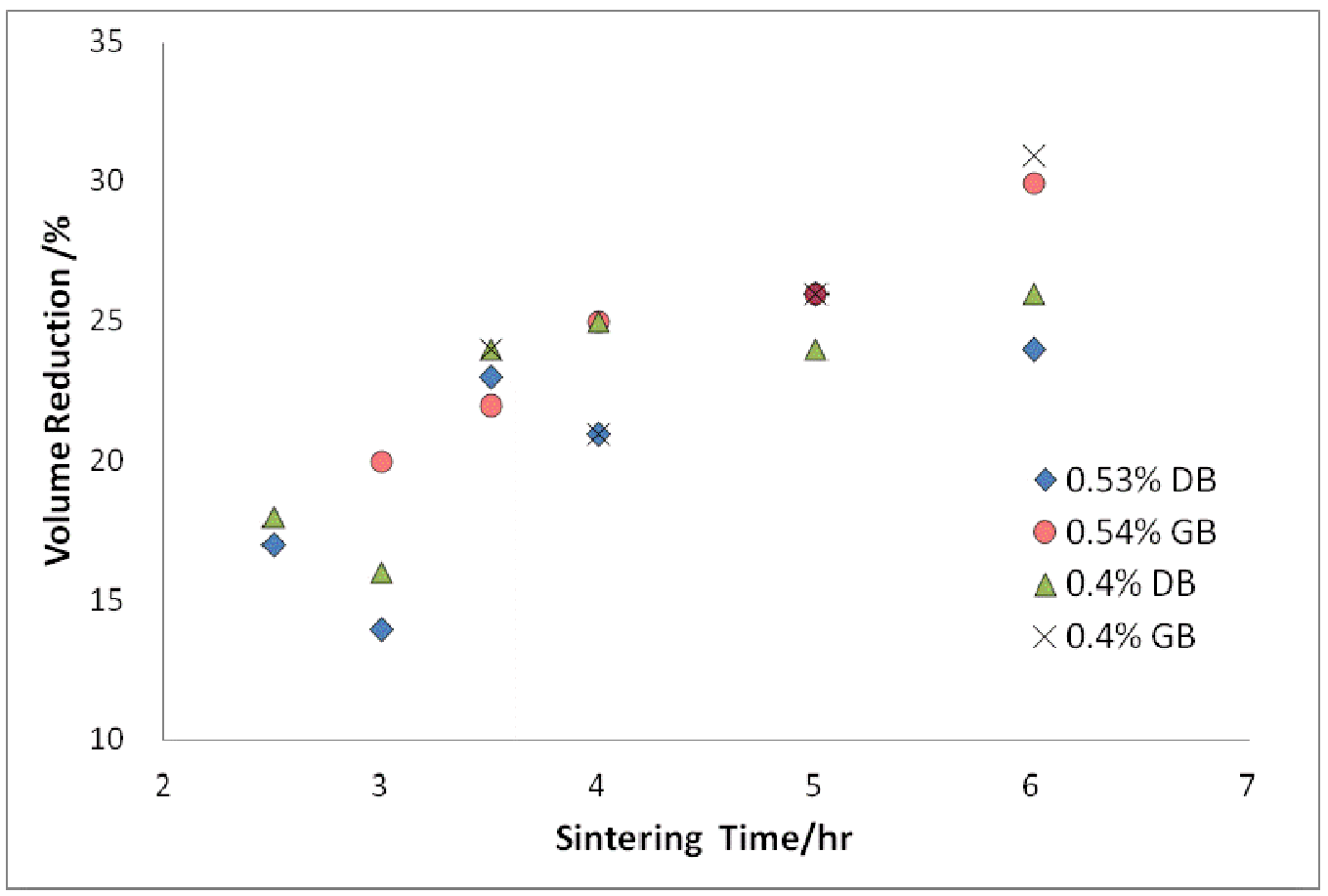

Fig. 6: Briquette volume changes versus time for sintering at $1200^{\circ} \mathrm{C}$

The results shown in Figs. 4-6 indicate that the briquette volume reduction is related to successes of the slag treatment. Without borates to stabilize higher temperature $\mathrm{Ca}_{2} \mathrm{SiO}_{4}$ polymorphs, the low temperature $\mathrm{Ca}_{2} \mathrm{SiO}_{4}$ polymorph, $\gamma-\mathrm{Ca}_{2} \mathrm{SiO}_{4}$, existing originally in the $\mathrm{Mg}$ slag was re-formed during cooling in the sintered briquettes. The briquettes then suffered volume expansion and disintegration, as the briquettes No. 55 seen in Figs. 4 and 5. The formation of higher temperature $\mathrm{Ca}_{2} \mathrm{SiO}_{4}$ polymorphs is accompanied by a $12 \%$ volume reduction. Thus a stabilization of the higher temperature polymorphs to room temperature by borates will retain the volume reduction, which also leads to a volume reduction for the sintered briquettes, as for the briquettes No. 1 and 25 and No. 37 and 25 seen in Figs. 4 and 5, respectively.

The clear dependence of the volume reduction on the time of briquette sintering shown in Fig. 6 reveals that both of the sintering time and borate addition are important parameters for treating the $\mathrm{Mg}$ slag. It requires a minimum $\mathrm{B}_{2} \mathrm{O}_{3}$ content of $0.1 \%$ for stabilization of $\mathrm{Ca}_{2} \mathrm{SiO}_{4}$ [28]. The borate 
particles in the slag should be in contact with $\mathrm{Ca}_{2} \mathrm{SiO}_{4}$ grains and be incorporated in the $\mathrm{Ca}_{2} \mathrm{SiO}_{4}$ crystal structure to form a solid solution with $\mathrm{Ca}_{2} \mathrm{SiO}_{4}$ phase, hence being able to stabilize the higher temperature $\mathrm{Ca}_{2} \mathrm{SiO}_{4}$ polymorphs to ambient temperature.

During the sintering, some parts of $\mathrm{B}_{2} \mathrm{O}_{3}$ in the borate particles may need to contact the $\mathrm{Ca}_{2} \mathrm{SiO}_{4}$ grains via diffusion. The velocity of solid state diffusion of $\mathrm{B}_{2} \mathrm{O}_{3}$ will be quite low at a low temperature. The rate of reaction for $\mathrm{B}_{2} \mathrm{O}_{3}$ to form a solid solution with $\mathrm{Ca}_{2} \mathrm{SiO}_{4}$ phase may also be limited at the low temperature. A time is thus required for $\mathrm{B}_{2} \mathrm{O}_{3}$ to contact $\mathrm{Ca}_{2} \mathrm{SiO}_{4}$ phase via diffusion and to form a solid solution with the phase.

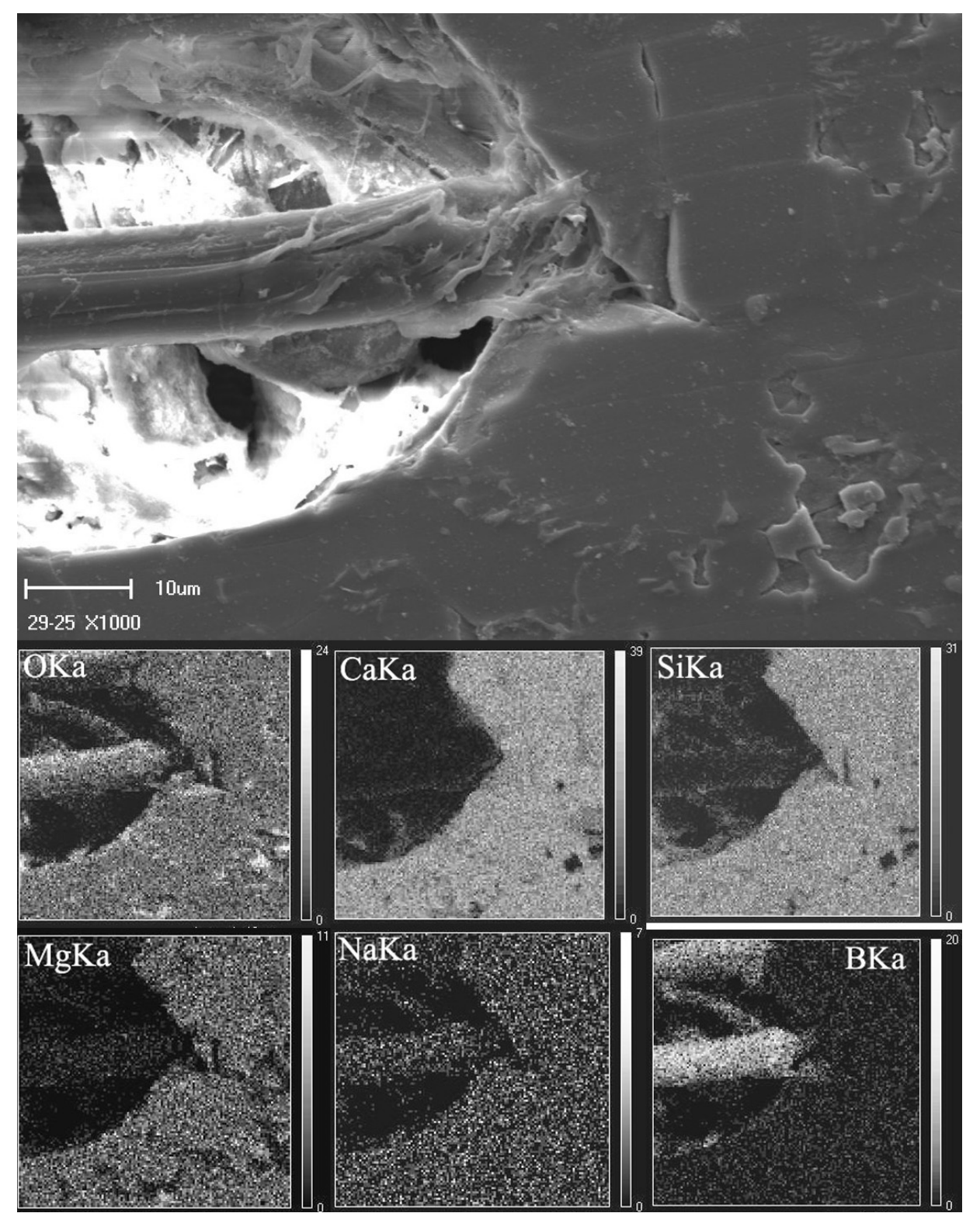

Fig. 7: SEM micrograph and element mapping of a briquette sample with GB addition of $0.54 \%$ and sintered at $1200^{\circ} \mathrm{C}$ for 3.5 hours in test 29

The rates for diffusion of $\mathrm{B}_{2} \mathrm{O}_{3}$ and its reaction with $\mathrm{Ca}_{2} \mathrm{SiO}_{4}$ phase may increase with raising of the sintering temperature and the amount of borates added. While the rates are enhanced the treatment time can be shorter.

The temperature for briquette sintering, $1200^{\circ} \mathrm{C}$, is higher than melting temperature for the borates, 696 and $742^{\circ} \mathrm{C}$, Table 1 . A formation of liquid borates did not shorten the sintering time. While sintered for less than 3 hour the briquette quality was often poor. A sintering time of 6 hours is needed 
for high quality briquettes or aggregates for building applications. This may by due, mainly, to the moderate amounts of borate addition, often less than $0.6 \%$. It may be necessary in later studies to develop more effective sintering methods for the Mg slag briquettes.

The upper part of Fig. 7 shows a SEM micrograph for a briquette sample with GB addition of $0.54 \%$ and sintered at $1200^{\circ} \mathrm{C}$ for 3.5 hours. The presence of a rod-like crystal with length of some 40 $\mu \mathrm{m}$ and width of about $10 \mu \mathrm{m}$ can be clearly observed just above the middle, horizontal line for the micrograph. The mapping shown in the lower part of Fig. 7 indicates existences of element $\mathrm{O}, \mathrm{Na}, \mathrm{Si}$, $\mathrm{Mg}, \mathrm{Ca}$ and $\mathrm{B}$. According to the FactSage simulation, Fig. 3, $\mathrm{MgOCa}_{3} \mathrm{O}_{3} \mathrm{SiO}_{4}$ (s) and $\mathrm{Na}_{2} \mathrm{Ca}_{2} \mathrm{Si}_{3} \mathrm{O}_{9}$ (s) can exist in the slag as minor phases. It is likely, based on the mapping and FactSage simulation, that the rod-like crystal may consist of $\mathrm{MgOCa}_{3} \mathrm{O}_{3} \mathrm{SiO}_{4}(\mathrm{~s})$ with $\mathrm{B}$ and $\mathrm{Na}$ in solid solution. It may also be the mineral $\mathrm{Na}_{2} \mathrm{Ca}_{2} \mathrm{Si}_{3} \mathrm{O}_{9}$ (s) with $\mathrm{B}$ and $\mathrm{Mg}$ dissolved. A high $\mathrm{B}$ intensity indicates a high content of $\mathrm{B}$ element in the rod-like crystal or just on the surface of the crystal. The sintering time of 3.5 hours may be too short for B to diffuse from the crystal to the neighboring zone with low B content.

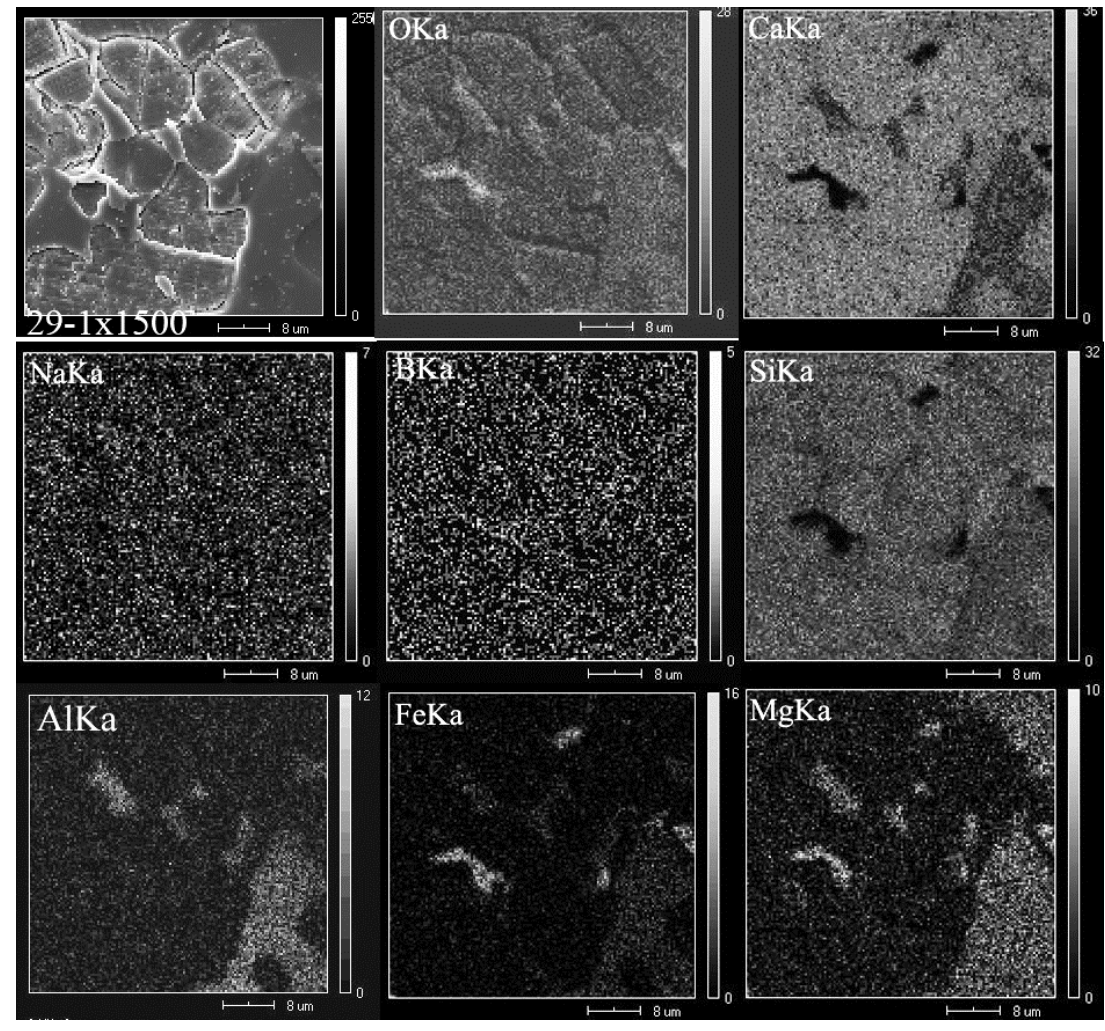

Fig. 8: SEM micrograph and element mapping of a briquette sample with DB addition of $0.53 \%$ and sintered for 3.5 hours at $1200^{\circ} \mathrm{C}$ in test 29

In the right part of SEM micrograph in Fig. 7, a flat and dense zone is observed, which is probably formed by $\mathrm{Ca}_{2} \mathrm{SiO}_{4}$ (s) minerals, judge by the mapping of $\mathrm{Ca}$ and $\mathrm{Si}$ elements. The mapping also displays an even distribution of both $\mathrm{Na}$ and $\mathrm{B}$ elements in the zoon and there is a higher content, intensity, for $\mathrm{Na}$ than for $\mathrm{B}$. $\mathrm{Na}$ ion or $\mathrm{B}$ ion can stabilize $\mathrm{Ca}_{2} \mathrm{SiO}_{4}$ by a Na-Ca substitution or a B-Si substitution $[20,28]$. $\mathrm{Na}$ and $\mathrm{B}$ element detected in the flat and dense zone may help each other contributing to the stabilization of the higher temperature $\mathrm{Ca}_{2} \mathrm{SiO}_{4}$ polymorphs to room temperature by the different ion substitutions.

Fig. 8 shows the SEM micrograph and element mapping for another briquette sample from the same test 29 but with $0.53 \% \mathrm{DB}$ added in the briquette. By referring to the mapping results, it can be deduced that $\mathrm{Ca}_{2} \mathrm{SiO}_{4}$ grains have occupied a large area in the micrograph and have formed solid solution with both $\mathrm{Na}$ and $\mathrm{B}$ ions, which are evenly distributed in the same area. The $\mathrm{Na}$ and $\mathrm{B}$ ions can thus stabilize the higher temperature $\mathrm{Ca}_{2} \mathrm{SiO}_{4}$ polymorphs by the ion substitution mechanisms. 
XRD results for sample (b), Fig. 2, show $\gamma-\mathrm{Ca}_{2} \mathrm{SiO}_{4}$ and $\mathrm{MgO}$ phases disappearing largely in the $\mathrm{Mg}$ slag sintered with a borate. The mapping in Fig. 8 demonstrates an existence of $\mathrm{MgO}$ containing mineral phases near the lower, right corner and in the area occupied by the $\mathrm{Ca}_{2} \mathrm{SiO}_{4}$ grains. The SEM mapping in Fig. 7 also reveals co-existences of $\mathrm{Mg}, \mathrm{Ca}$ and $\mathrm{Si}$ elements, not only in the rod-like crystal, but also in the flat and dense zone rich in $\mathrm{Ca}_{2} \mathrm{SiO}_{4}(\mathrm{~s})$ minerals. Besides formations of $\mathrm{MgOCa}_{3} \mathrm{O}_{3} \mathrm{SiO}_{4}(\mathrm{~s})$ and $(\mathrm{MgO})\left(\mathrm{Fe}_{2} \mathrm{O}_{3}\right)(\mathrm{s})$ phase predicted by FactSage in Fig. 3, $\mathrm{MgO}$ can also react with $\mathrm{Al}_{2} \mathrm{O}_{3}$ forming $\mathrm{MgAl}_{2} \mathrm{O}_{4}$ [4]. The $\mathrm{Mg}$ and $\mathrm{Al}$ elements detected near the lower, right corner in the SEM mapping of Fig. 8 may prove the formation of $\mathrm{MgAl}_{2} \mathrm{O}_{4}$ in the sintered briquettes.

Both the observations in SEM micrographs in Figs. 7 and 8 and FactSage simulation in Fig. 3 reveal existences of stable mineral phases containing $\mathrm{MgO}$. It may then be deduced that, by sintering mixtures of $\mathrm{Mg}$ slag powder and borates, it is possible to not only eliminate the $\gamma-\mathrm{Ca}_{2} \mathrm{SiO}_{4}$ but also decrease the content of free $\mathrm{MgO}$, thus making the slag a building material with high volumetric stability.

Suggestions. Based on the results from the present tests it is suggested that two of the three borate agents, DB and GB, should be preferably selected for treating the $\mathrm{Mg}$ slag powder, as the $\mathrm{Na}_{2} \mathrm{O}$, $30.8 \%$ in $\mathrm{DB}$ and $23.5 \%$ in $\mathrm{GB}$, can also stabilize the higher temperature $\mathrm{Ca}_{2} \mathrm{SiO}_{4}$ polymorphs.

For treatment of the $\mathrm{Mg}$ slag at $1200^{\circ} \mathrm{C}$ it is recommended to add at least $0.4 \% \mathrm{DB}$ and $\mathrm{GB}$ or $0.6 \%$ $\mathrm{H}_{3} \mathrm{BO}_{3}$ and to sinter the slag-borate briquettes for the time not less than 5 hours.

The Mg slag powder after sintering with borates addition according to the suggested procedures will be volume stable and can be used in building applications to replace valuable natural aggregates.

\section{Conclusions}

A sample of $\mathrm{Mg}$ slag powder from the local magnesium production plant was obtained for characterization and treatment tests. The following results have been obtained:

1. Results of XRD analysis and equilibrium phase calculation by FactSage 6.2 indicate that $\gamma-\mathrm{Ca}_{2} \mathrm{SiO}_{4}$ exists as a major phase in the $\mathrm{Mg}$ slag, causing the slag to disintegrate.

2. The $\mathrm{Mg}$ slag fines were mixed with borates to make slag-borate briquettes for sintering treatments. By sintering at $1200^{\circ} \mathrm{C}$ for 3-6 hours, the briquette color was changed from light grey to dark brown. There was also a volume reduction of $20-30 \%$ for the sintered slag-borate briquettes. $\mathrm{XRD}$ analysis indicates a reduction of both $\gamma-\mathrm{Ca}_{2} \mathrm{SiO}_{4}$ and free $\mathrm{MgO}$ phase in the briquette sample.

3. It was found from studies of SEM micrographs of sintered briquette samples that $\mathrm{Na}$ and $\mathrm{B}$ ions from the added borates exist together with $\mathrm{Ca}$ and $\mathrm{Si}$ elements. It is then possible for the two irons to stabilize the higher temperature $\mathrm{Ca}_{2} \mathrm{SiO}_{4}$ polymorphs by ion substitution mechanisms, which prevents a re-formation of $\gamma-\mathrm{Ca}_{2} \mathrm{SiO}_{4}$ in the slag. The SEM results reveal also a decrease of free $\mathrm{MgO}$ content in the sintered briquettes.

4. The present test results indicate that an effective treatment for the $\mathrm{Mg}$ slag powder can be achieved by adding borates of $0.4-0.6 \%$ to form a slag-borate mixture for sintering at $1200^{\circ} \mathrm{C}$ in a time period not less than 5 hours. After the treatment it may be possible to use the obtained slag aggregates as building materials, which will save valuable natural resources and decreasing the global warming impact of magnesium production.

\section{Acknowledgements}

The work was supported by International Science and Technology Cooperation projects (2010DFB50140) and the Natural Science Foundation of Ningxia Hui Autonomous Region (NZ0952) in China.

Besides, researches from Beifang University of Nationalities and Luleå University of Technology, LTU, have also received financial support from CAMM, Center for Advanced Mining and Metallurgy, at LTU, for visiting and for performing joint research work. The authors wish to thank Prof. Bo Björkman, LTU, who kindly made arrangements for the CAMM financial support and the researcher visiting. 


\section{References}

[1] CARLOS H. CACERES: Metallurgical and Materials Transactions A, 38A (2007), p 1649

[2] MORDIKE B L, EBERT T: Mater Sci Eng A, 302 (2001), p. 37-45

[3] M. A. Najafabadi, M. Hirasawa and M. Sano: ISIJ Int., 36 (1996), p. 1366

[4] J. Yang, et al.: ISIJ Int., 41 (2001), p 945

[5] Haiping SUN, Yung-Chang LI and Muh-Jung: ISIJ Int., 49 (2009), p 771-776.

[6] Editorial Column, The yearbook of nonferrous metals industry of China 2005 [M]. Beijing, China Nonferrous Metals Industry Association (2005), p. 503-504 (in Chinese)

[7] MENG Shu-kun: J. China Metal Bulletin, 21 (2006), p 3-10 (in Chinese)

[8] CHEN Wan-kun, SHI Jun-wu: [M]. Changsha, Central South University of Technology Press, (1995) p. 165 (in Chinese)

[9] Zang JC: In: Hryn J, editor. Magnesium technology Proceedings of the Minerals, Metals and Materials Society Meeting 2001, New Orleans, Louisiana, 11-15 February (2001), p. 7-10

[10] MA Hongwen, et al,: GEOSCIENCE, Vol 22, No. 5 (2008) p. 829

[11] Feng GAO, Zuo-ren NIE et al: Trans. Nonferrous Met. Soc. China 18 (2008), p. 749 (in Chinese) [12] Pidgeon LM, Alexander WA: in New York Meeting: reduction and refining of non-ferrous metals, Trans Am Inst Mining Mater Eng 159 (1944), p. 315

[13] Toguri JM, Pidgeon LM: Can J Chem., 40 (1962), p. 1769

[14] RAMAKRISHNAN S, KOLTUN P: [J]. Resources Conservation \& Recycling, 24,(2004), p. 49

[15] Jingkuan Li et al.: J. of Taiyuan University of Technology, Vol 39, No 6 (2008) p. 574 (in Chinese)

[16] Congyun Huang et al.: Cement Guide for New Epoch, No. 5 (2005) p. 27 (in Chinese)

[17] H. Motz and J. Geiseler: Waste Management, Vol 21, Issue 3, (2001), p. 285-293

[18]Qixing Yang et al.: in Proceedings of The $7^{\text {th }}$ Nordic-Japan Symposium on Science and Technology of Process Metallurgy, Jernkontoret, Stockholm, September 15-16, (2005)

[19] Qixing Yang et al.: in Proceedings of The Iron \& Steel Technology Conference, AISTech 2006, May 1-4, 2006, Cleveland, Ohio, USA. Volume 1, p. 573

[20] Surendra N. et al.: Journal of Materials Science, 14 (1979), p. 1554-1566

[21] Dirk Durinck et al.: globalslagMAGAZINE March (2008), p. 25

[22] T. A. Branca et al.: Ironmaking and Steelmaking, Vol. 36, No. 8 (2009), p. 597

[23]Zizhi Cui et al.: Fly Ash Comprehensive Utilization, No. 6 (2006), p. 8 (in Chinese)

[24]Zizhi Cui et al.: J. of Ningxia University (Natural Science Edition), Vol. 29, No. 3 (2008) p. 230 (in Chinese)

[25] Aiqin ZHAO: Shanxi Architecture, Vol. 29, No. 17, (2003) p. 48(in Chinese)

[26] Qixing Yang et al.: in Proceedings of REWAS2008, Global Symposium on Recycling, Waste Treatment and Clean Technology, edited by Dr. B. Mishra et al., A Publication of TMS

[27] Qixing Yang et al.: In: Proceedings of the VIII international conference on molten slags, fluxes and salts, Gecamin, (2009) p. 33-41

[28] Dirk Durinck et al.:J. Am. Ceram. Soc., 91 [2], (2008), p. 548

[29] C.W. Bale et al.: CALPHAD: Computer Coupling of Phase Diagrams and Thermochemistry 33 (2009) p. 295-311 


\section{Materials Processing Technology}

10.4028/www.scientific.net/AMR.418-420

Treatments of Magnesium Slag to Recycle Waste from Pidgeon Process

10.4028/www.scientific.net/AMR.418-420.1657 